\title{
THe PRICE OF POWER: Valuing the Controlling Position of OWNer-Managers IN FRENCH IPO FIRMS
}

\section{Peter Roosenboom and Willem Schramade}

\begin{tabular}{|l|l|}
\hline \multicolumn{2}{|l|}{ ERIM REPORT SERIES RESEARCH IN MANAGEMENT } \\
\hline ERIM Report Series reference number & ERS-2005-011-F\&A \\
\hline Publication & February 2005 \\
\hline Number of pages & 40 \\
\hline Email address corresponding author & p.roosenboom@rsm.nl \\
\hline Address & Erasmus Research Institute of Management (ERIM) \\
& Rotterdam School of Management / Rotterdam School of \\
& Economics \\
& Erasmus Universiteit Rotterdam \\
& P.O. Box 1738 \\
& 3000 DR Rotterdam, The Netherlands \\
& Phone: $\quad+31104081182$ \\
& Fax: $\quad+31104089640$ \\
& Email: info@erim.eur.nl \\
& Internet: $\quad$ www.erim.eur.nl \\
\hline
\end{tabular}

Bibliographic data and classifications of all the ERIM reports are also available on the ERIM website: www.erim.eur.nl 


\section{ERASMUS RESEARCH INSTITUTE OF MANAGEMENT}

\section{REPORT SERIES}

\section{RESEARCH IN MANAGEMENT}

\begin{tabular}{|c|c|c|}
\hline \multicolumn{3}{|c|}{ BIBLIOGRAPHIC DATA AND CLASSIFICATIONS } \\
\hline Abstract & \multicolumn{2}{|c|}{$\begin{array}{l}\text { Going public often creates an agency conflict between the owner-manager and minority } \\
\text { shareholders. This problem is especially severe in countries with poor legal investor } \\
\text { protection, such as France. We examine the controlling position of owner-managers in } \\
\text { French IPO firms. We find that investors anticipate the increased agency conflict } \\
\text { associated with a lock on control and lower firm value when the owner-manager is more } \\
\text { powerful. Shareholder agreements in which the owner-manager agrees to share control } \\
\text { with other pre-IPO owners enhance firm value. We also report that higher cash flow } \\
\text { ownership by the owner-manager is positively related to firm value when he is not in full } \\
\text { control. Finally, we document that the large (non-pecuniary) private benefits of control } \\
\text { in France may motivate owner-managers to retain control after the IPO. }\end{array}$} \\
\hline \multirow{3}{*}{$\begin{array}{l}\text { Library of Congress } \\
\text { Classification } \\
\text { (LCC) } \\
\text { LCC Webpage }\end{array}$} & \multicolumn{2}{|c|}{ Mission: HF 5001-6182 } \\
\hline & \multicolumn{2}{|l|}{ Programme: HF 4001-4280.7 } \\
\hline & Paper:HG4028.S7 & Going public \\
\hline \multirow{3}{*}{$\begin{array}{l}\text { Journal of Economic } \\
\text { Literature } \\
\text { (JEL) } \\
\text { JEL Webpage }\end{array}$} & \multicolumn{2}{|l|}{ Mission: M } \\
\hline & \multicolumn{2}{|l|}{ Programme : $\mathrm{G} 3$} \\
\hline & Paper: G 32 & Capital and ownership structure \\
\hline \multicolumn{3}{|c|}{ Gemeenschappelijke Onderwerpsontsluiting (GOO) } \\
\hline \multirow[t]{3}{*}{ Classification GOO } & \multicolumn{2}{|l|}{ Mission: 85.00} \\
\hline & \multicolumn{2}{|l|}{ Programme: 85.30} \\
\hline & Paper: 85.30 & Financieel management \\
\hline \multirow[t]{3}{*}{ Keywords GOO } & \multicolumn{2}{|l|}{ Mission: Bedrijfskunde / Bedrijfseconomie } \\
\hline & \multicolumn{2}{|c|}{ Programme: Financieel management, besliskunde } \\
\hline & \multicolumn{2}{|c|}{ Paper:Eigendomsverhoudingen, IPO's, Frankrijk } \\
\hline Free keywords & \multicolumn{2}{|c|}{ Ownership structure, initial public offerings (IPOs), going public } \\
\hline
\end{tabular}




\title{
The Price of Power: \\ Valuing the Controlling Position of Owner-Managers in French IPO Firms
}

\author{
Peter Roosenboom* \\ Erasmus University Rotterdam \\ Willem Schramade \\ Erasmus University Rotterdam
}

\begin{abstract}
Going public often creates an agency conflict between the owner-manager and minority shareholders. This problem is especially severe in countries with poor legal investor protection, such as France. We examine the controlling position of owner-managers in French IPO firms. We find that investors anticipate the increased agency conflict associated with a lock on control and lower firm value when the owner-manager is more powerful. Shareholder agreements in which the owner-manager agrees to share control with other pre-IPO owners enhance firm value. We also report that higher cash flow ownership by the owner-manager is positively related to firm value when he is not in full control. Finally, we document that the large (non-pecuniary) private benefits of control in France may motivate owner-managers to retain control after the IPO.
\end{abstract}

JEL codes: G32, G34

Keywords: ownership structure, initial public offerings (IPOs), going public

* Corresponding author. The usual disclaimer applies. Correspondence address: Department of Financial Management, Faculty of Business, Erasmus University Rotterdam, PO Box 1738, 3000 DR Rotterdam, The Netherlands. Phone: +31 10408 1255, Fax: +31 10408 9017, Email: p.roosenboom@fbk.eur.nl, w.schramade@fbk.eur.nl. An anonymous referee of this journal and Jeffry Netter (the editor) provided valuable comments that substantially improved earlier versions of the manuscript. We thank Jana Fidrmuc, Abe de Jong, Rezaul Kabir, Piet Moerland and Marieke van der Poel for their valuable comments and suggestions on an earlier draft of this paper. We thank seminar participants at Erasmus University Rotterdam and the 2003 EFMA conference in Helsinki for their helpful comments and suggestions. 


\title{
The Price of Power: Valuing the Controlling Position of Owner-Managers in French IPO Firms
}

\begin{abstract}
Going public often creates an agency conflict between the owner-manager and minority shareholders. This problem is especially severe in countries with poor legal investor protection, such as France. We examine the controlling position of owner-managers in French IPO firms. We find that investors anticipate the increased agency conflict associated with a lock on control and lower firm value when the owner-manager is more powerful. Shareholder agreements in which the owner-manager agrees to share control with other pre-IPO owners enhance firm value. We also report that higher cash flow ownership by the owner-manager is positively related to firm value when he is not in full control. Finally, we document that the large (non-pecuniary) private benefits of control in France may motivate owner-managers to retain control after the IPO.
\end{abstract}

JEL codes: G32, G34

Keywords: ownership structure, initial public offerings (IPOs), going public 


\section{Introduction}

At the time of an initial public offering (IPO) the owner-manager seeks to raise capital from outside investors or to cash out part of his shareholdings. Even after the firm has gone public, the entrepreneur often acts as the controlling owner and manager. This creates an agency conflict between the owner-manager and minority shareholders (Jensen and Meckling, 1976).

In this study, we examine the impact of the controlling position of French ownermanagers on IPO firm value. The agency conflict is especially severe in France because of its poor legal protection of minority shareholders (La Porta et al., 1999). In addition, France is a country characterized by concentrated ownership and large private benefits of control (Johnson et al., 2000). In particular, Fanto (1998) documents that French managers have a responsibility to serve the social interest (intérêt social) rather than shareholder interests. Alcouffe (2000) argues that this principle of social interest increases managerial discretion and encourages the owner-manager to pursue his own interests usually at the expense of minority shareholders.

We analyze a sample of 299 IPOs on the Paris Bourse from January 1993 to December 1999. We study IPO firms because the position of their owner-managers closely matches the situation in Jensen and Meckling (1976), where an existing ownermanager attempts to sell equity to outside investors. Outside investors know that the owner-manager may take actions that are not in their best interest. In practice, the IPO prospectus often mentions this as one of the risk factors associated with investing in IPO shares ${ }^{1}$. Therefore, investors are likely to anticipate the agency costs and 'price protect' themselves. This 'price protection' shows up as a discount on firm value.

\footnotetext{
${ }^{1}$ For example: "The controlling shareholder will have the ability to determine the outcome of matters submitted to our shareholders for approval at the general meeting, including the election and removal of directors and any merger, consolidation or sale of all or substantially all of our assets. Such control and concentration of ownership may affect the market price of the securities and may lead to a conflict with minority shareholders." (translated from the IPO prospectus of RISC Technology dated 9 November 2000, page 68).
} 
The owner-manager can mitigate the agency problem by bonding mechanisms that better align his interests with those of the minority shareholders. Post-IPO cash flow ownership is one of these bonding mechanisms. Because the owner-manager bears direct wealth consequences from his decisions through his cash flow ownership, private benefits of control become costly to him and will be reduced (La Porta et al, 2002). This is called the incentive effect of the owner-manager's controlling position and is expected to have a positive effect on firm value. In addition, shareholder agreements have the potential to limit expropriation of minority shareholders (Chemla et al., 2002). These shareholder agreements are private contracts among shareholders with the purpose to share control among pre-IPO owners and are expected to enhance IPO firm value.

However, the incentive effect associated with cash flow ownership might be offset by an entrenchment effect. Large private benefits of control make it desirable to maintain a lock on control. In France, this lock can be maintained by separating votes from cash flow rights by employing pyramidal structures and double voting rights. In theory, this increases the agency conflict between the owner-manager and minority shareholders (Bebchuk et al., 2000). We hypothesize that investors will anticipate larger agency costs if post-IPO control by the owner-manager is high, and that they will 'priceprotect' themselves through a larger discount on IPO firm value.

We make three contributions to the literature. First, we extend recent studies dealing with ownership and control in IPO firms. For example, Smart and Zutter (2003) examine the use of dual class share structures by U.S. IPO firms. They find that the dual class IPOs sell at lower price-to-sales ratios than single class IPOs. Field and Karpoff (2002) show that managers of U.S. IPO firms are more likely to use takeover defenses when they have large private benefits of control. Unlike these studies, we are able to disentangle incentive and entrenchment effects associated with controlling ownermanagers. Second, we examine the use of shareholder agreements between the ownermanager and other pre-IPO shareholders. French IPO prospectuses contain detailed descriptions of these shareholder agreements, an institutional detail that allows us to 
deepen our analysis. Third, we investigate whether (non-pecuniary) private benefits motivate French owner-managers to keep a lock on control. In particular, we examine proxies for nepotism, status and prestige.

We find that the cash flow ownership of the owner-manager is positively related to IPO firm value (consistent with an incentive effect), whereas the power he derives from his cash flow ownership is negatively related to IPO firm value (consistent with an entrenchment effect). The use of shareholder agreements is positively related to IPO firm value. This is consistent with shareholder agreements reducing expropriation of minority shareholders. Finally, we document that non-pecuniary private benefits are higher when the owner-manager retains full control of the IPO firm.

The organization of the rest of the paper is as follows. Section two develops hypotheses. Section three presents the data and methods. Section four discusses the results. Section five concludes.

\section{Hypothesis development}

\subsection{Cash flow ownership of the owner-manager}

Jensen and Meckling (1976) show that the owner-manager will consume more private benefits once he has sold shares to the public. This creates an agency problem. Outside investors will try to moderate the consumption of these private benefits through costly monitoring. As long as prospective shareholders form rational expectations about the actions of the owner-manager, the price they are willing to pay for the shares will reflect these agency costs. The owner-manager therefore bears the expected agency costs to the extent he owns shares in the company and trades off these costs against the utility he derives from his private benefits (Bebchuk, 1999). The principal-agent model of Jensen and Meckling (1976) predicts a positive relation between management stock ownership and firm value. If managers own more stock in the employing company, they internalize 
a larger fraction of the costs associated with their shirking and perk consumption. As a result, the incentives to consume private benefits are reduced and firm value is increased (La Porta et al., 2002). Building on this research, we hypothesize,

Hypothesis 1a. Post-IPO cash flow ownership of the owner-manager is positively related to IPO firm value.

However, the theoretical model of Stulz (1988) predicts that the relationship between cash flow ownership and firm value is non-linear. As cash flow ownership and control of the owner-manager increase beyond a certain threshold, a negative effect on firm value associated with the ability to block value-enhancing takeovers (i.e., entrenchment) may dominate the incentive benefits associated with cash flow ownership. Accordingly, McConnell and Servaes (1990) report a curvilinear relationship between firm value and management ownership. As predicted by principal-agent theory, the relation is positive at low levels of ownership, since the owner-manager has an incentive to maximize value as his ownership increases. However, if his ownership gets larger, it becomes more difficult for outside shareholders to control him. The owner-manager may therefore, after a point, become entrenched and indulge his preferences for private benefits such as shirking and perk consumption that reduce firm value. Hence,

Hypothesis 1b. Post-IPO cash flow ownership of the owner-manager has a curvilinear relationship with IPO firm value.

\subsection{Mechanisms to separate voting rights from cash flow rights}

A controlling owner may treat himself preferentially at the expense of other investors, especially if his voting power is significantly larger than his cash flow ownership. Bebchuk (1999) develops a rent protection theory of corporate ownership and control. In 
his theory, an owner-manager has to decide whether he stays in control when the company goes public. If the private benefits of control are large and transferable, the owner-manager decides to keep a lock on control. If he left control contestable, rival management teams would seize power of the company to capture these large private control rents. As a result, publicly traded companies tend to have a controlling owner in countries where private benefits of control are large (La Porta et al., 1999).

Bebchuk et al. (2000) show that the separation of cash flow and voting rights has the potential to create very large agency costs. This separation allows a controlling shareholder to maintain a lock on control without holding the majority of cash flow rights. It also makes holding a lock on control less expensive because it does not require controlling owners to forego the benefits of diversification to the same extent as under a 'one share-one vote' rule. As a result, the controlling owner does not internalize a large fraction of the wealth consequences of his decisions through his cash flow ownership. For example, the owner-manager can adopt a dual class equity structure. Under dual class equity, the owner-manager retains high voting shares and sells lower voting shares to the public.

Alternatively, pyramid structures allow the controlling shareholder to exercise control through a chain of companies. In a two-tier pyramid structure, a controlling shareholder holds a controlling vote in a holding company that in turn holds a controlling stake in an operating company. Several more layers can be added, which allows the owner at the top of the pyramid to control all the companies in the pyramid structure with an increasingly small investment in each firm further down the pyramid. This effectively separates voting and cash flow ownership. Grossman and Hart (1988) theoretically show that the separation of ownership and voting rights can lower shareholders' value. We therefore hypothesize,

Hypothesis 2. The extent of separation between cash flow rights and voting rights in the hands of the owner-manager is negatively related to IPO firm value. 


\subsection{Sharing control}

Bennedsen and Wolfenzon (2000) theoretically show that multiple large shareholders none of which can control the firm without agreeing with one or more of the other shareholders - may limit expropriation of minority shareholders. Because none of the shareholders is large enough to be in unilateral control, they need to form coalitions in order to obtain majority control. Such coalitions, by aggregating the cash flow ownership of their members, internalize the wealth consequences of their actions to a larger extent than their individual members do. As a result, the consumption of value-reducing private benefits of control is reduced. Similarly, Gomes and Novaes (2001) show that, by sharing control with other large shareholders, the owner-manager limits the expropriation of minority shareholders. This effect arises from the bargaining problems associated with multiple large shareholders. A large shareholder will not agree to lower firm value because of the private benefits that another large shareholder might enjoy.

Shareholder agreements are an example of a private contract among shareholders with the purpose to share control and limit expropriation. They may include several clauses. For example, pre-emptive rights that give precedence to contracting shareholders in buying each other's stakes at fair value, drag-along rights that allow contracting shareholders to force one another to join them in selling their shares to an acquirer and pooling (or voting) agreements that allow each contracting shareholder to nominate a certain number of candidates for the board of directors. Chemla et al. (2002) theoretically show that shareholder agreements preserve the incentive to make ex ante investments and minimize ex post transfers. We therefore hypothesize that shareholder agreements have a positive impact on IPO firm value.

Hypothesis 3. The presence of shareholder agreements is positively related to IPO firm value. 
Building on the previous research, we argue that an owner-manager is likely to enjoy larger private benefits of control if he does not have to reach an agreement or form a coalition with other shareholders. We expect that investors anticipate the larger propensity to consume private control benefits once the owner-manager shares limited or no power with other shareholders. According to agency theory, investors then engage in 'price-protection' and reduce the price they are willing to pay for the shares. We call this the 'entrenchment' effect. This suggests the following hypothesis:

Hypothesis 4. The strength of the post-IPO power of the owner-manager vis-à-vis other shareholders is negatively related to IPO firm value.

\subsection{Private benefits of control}

Coffee (2001) defines private benefits of control as: "all the ways in which those in control of a corporation can siphon off benefits to themselves that are not shared by the other shareholders" (page 9). These private benefits of control are inherently difficult to measure directly. Nenova (2003) uses price differences between two classes of stock with identical cash flow rights but differing voting rights to measure private benefits, and finds that control rents are larger in countries with poor investor protection. Dyck and Zingales (2004) measure private benefits as the difference between prices paid in a control block purchase and market prices. They find that private benefits are associated with less developed capital markets and more concentrated ownership. Field and Karpoff (2002) show that managers of U.S. IPO firms are more likely to use takeover defenses when they have large private benefits of control in the form of cash compensation.

These prior studies focus on monetary private benefits of control that are transferable to an outside acquirer. However, non-monetary or psychic private benefits may be equally important. These psychic private benefits include status, prestige and 
amenities that are not easily transferred to other owners. For example, one of the privileges of control is the owner-manager's ability to employ family members and to appoint them on the board (nepotism). Family board members may be problematic, both in executive and in non-executive roles. First, Barth et al. (2005) report that firms run by family executives are less productive than firms (including family firms) run by professional managers. Second, non-executive family directors are indebted to the owner-manager and less likely to discipline him because of the consequences that these actions have on family relationships inside the firm and among the extended family outside the company (Anderson and Reeb, 2003). Ehrhardt and Nowak (2003) find that German family firms are more likely to adopt dual class shares structures when the firm is an important employer in a small town (status and prestige).

Preservation of private benefits of control is costly, because concentrated ownership may force the owner-manager to be not well diversified. Thus, if he is willing to bear the loss of diversification and remain in full control, the private benefits of control are expected to be large (Bebchuck, 1999).

Hypothesis 5. Private benefits are larger when the owner-manager is in full control.

\section{Data and methods}

\subsection{Sample and data collection}

We start with the complete universe of French IPO firms from January 1993 to December 1999. IPO firms are identified by L'Année Boursière, an annual publication of the Société des Bourses Françaises (SBF). Following Derrien and Womack (2003), we exclude 21 domestic firms that listed on the Premier Marché (the most prestigious listing venue in France), because they generally involve privatization, equity carve-outs or spinoffs. Twenty-eight firms that transferred from the Marché hors-cote (an OTC market that 
existed until 1998), or that previously traded on a foreign stock market, are excluded because their price discovery is straightforward. We drop twelve financial services firms (SIC codes 6000-6999) because their reporting environments are different from those of other IPO firms. For the same reason, nine firms that listed either on one of the six regional stock exchanges (Bordeaux, Lille, Lyon, Marseilles, Nantes, and Nancy) or on the Marché Libre (an unregulated trading platform in France) are dropped. The filters result in a sample of 299 non-financial French firms that go public on either the Nouveau Marché (98 firms) or the Second Marché (201 firms) of the Paris Bourse. The sample is nearly equally divided in manufacturing (100 firms), non-financial services (112 firms) and high-tech industries (87 firms) $)^{2}$.

\subsection{Variable measurement}

\subsubsection{Firm and offer characteristics}

Table 1 presents descriptive characteristics. Offer prices and financial statement numbers are taken from prospectuses ${ }^{3}$. Market value is measured as the number of shares outstanding after the IPO times the closing price on the first-day of trading. Market prices are collected from Datastream. The median market value on the first day of trade amounts to $€ 41$ million with a minimum of $€ 10.7$ million and a maximum of $€ 827$

\footnotetext{
${ }^{2}$ Manufacturing companies are active in SIC codes starting with 15, 17, 20, 22, 23, 24, 26, 27, 28 (not 283), 30, 31, 32, 33, 34, 35 (not 357), 36 (not 365, 366, 367), 37 (not 376), 38 (not 382, 384) and 39. Nonfinancial services firms operate in SIC codes starting with $42,47,49,50,51,52,55,56,57,58,59,70,72$, 73 (not 737), 75, 76, 78, 79, 80, 84, 87 (not 8731), and 89. High-tech companies are active in SIC codes starting with $283,357,365,366,367,376,382,384,48,737$, and 8731 .

${ }^{3}$ Companies that intend to list on the French equity markets have to file their IPO prospectus with the Commission des Opération de Bourse (COB), the French equivalent of the Securities and Exchange Commission (SEC). Firms must gain prior approval of the $\mathrm{COB}$ by the granting of a visa (COB regulation 98-01). If the shares are to be listed, a complete prospectus has to be filed with the COB at least 15 days beforehand. This period is reduced to two days if the firm has previously registered a document de référence. The latter is comparable to an annual report in that it may serve as a basic disclosure document although it contains no transaction-specific information. To fill the resulting information gap, a company relying on a document de référence must file a note d'opération which describes the offered shares and, if necessary, contains an update of the information in the document de référence. If the shares are to be listed on the Nouveau Marché, the firm is required to file a prospectus at least two months in advance.
} 
million. Offering proceeds are defined as the number of shares offered to the public times the final offer price. Median offering proceeds amount to $€ 7.3$ million. The median number of shares sold to the public equals 20 percent of the shares outstanding after the IPO. The first-day return, measured as the offer-to-close return on the first day of trade, averages about 14.4 percent. The average (median) sales for the last 12 month financial period are equal to $€ 64.4$ million ( $€ 24.8$ million). The cash flow margin is defined as the sum of earnings before interest, taxes, depreciation, amortization (EBITDA) and provision allowances divided by sales for the last 12 months reported in the prospectus. The cash flow margin is 15.5 percent of sales at the median. Plant, property and equipment reported on the most recent balance sheet in the prospectus equals $17.9 \%$ of total assets. The median age of IPO firms is 16 years. To calculate the market-to-book ratio, the market value on the first day of trade is divided by the sum of the proceeds from the newly issued shares and the book value of equity from the last pre-IPO financial statement, or when available from a later interim report included in the prospectus. The market-to-book ratio averages 4.45 and yields 3.65 evaluated at the median.

[Please insert Table 1 and Table 2 about here]

We determine the price-to-book ratio as the preliminary offer value divided by the pre-IPO book value of equity. Preliminary offer value is computed as the number of pre-IPO shares outstanding times the preliminary offer price. The preliminary offer price equals the minimum tender price (auctions) or the midpoint of the price range (bookbuilding) or the offer price (fixed-price offerings) ${ }^{4}$. Pre-IPO book value of equity is taken from the last pre-IPO financial statement, or when available from a later interim

\footnotetext{
${ }^{4}$ In France, firms can choose between different IPO selling mechanisms. The Offre à Prix Minimal (OPM) is a single-bid auction in which a minimum tender price is set beforehand. The auction procedure is selected by 100 firms in our sample. In a fixed-price offering or Offre à Prix Ferme (OPF) a fixed number of shares is offered at a fixed price. The fixed-price offering is used by 19 sample firms. Since 1993, French IPOs can also be made through a placing or Placement Garanti (PG). This procedure corresponds to the bookbuilding procedure that is used in the United States. The bookbuilding procedure is adopted by
} 
report included in the prospectus. We find that the price-to-book ratio has an average of 6.84 and a median of 4.95 . We compute the price-to-cash flow ratio as the ratio between the preliminary offer value and the sum of EBITDA and provision allowances for the last 12 month period included in the prospectus. We report an average price-to-cash flow ratio equal to 12.11 and a median price-to-cash flow ratio of 8.51 .

\subsubsection{Ownership and voting structure}

Table 2 shows the average post-IPO cash flow ownership (Panel A) and voting (Panel B) structure. The table reports unconditional averages and averages conditional on that particular class of shareholder owning stock in the IPO firm. Data come from IPO prospectuses. In France, it is possible to separate voting rights and cash flow rights using a double voting rule (droit de vote double). However, these multiple voting stocks do not represent a special category of stocks in France. Under this rule, ordinary shares carry double votes after holding them for either 2, 3 or 4 years, depending on the provisions in the company's statutes. The company is free to adopt the 2, 3 or 4 years holding period requirement but can only adopt one of these holding periods in its statutes. In our sample, $83 \%$ of IPO firms apply a double voting rule, which takes effect after either 2 years $(39.5 \%), 3$ years $(8.7 \%)$ or 4 years $(34.8 \%)$. This implies that any shareholder who meets the holding period requirement of either 2, 3 or 4 years is entitled to cast two votes per share. The percentage of votes reported by each pre-IPO shareholder is required to incorporate any effects of double voting rules.

Another method to separate cash flow and voting rights is a pyramid structure. The owner-manager is said to be controlling the firm through a pyramid if he controls the company through another company that he does not completely own. Following La Porta et al. (1999), we require that the owner-manager controls at least $20 \%$ of the votes in

180 firms. For a more detailed discussion of French IPO selling mechanisms see Derrien and Womack (2003). 
each of the companies in the pyramid. For example, if the owner-manager owns $20 \%$ of the voting and cash flow rights of company A that in turn controls $25 \%$ of the votes and cash flow rights of company $\mathrm{B}$, we say that the owner-manager controls company $\mathrm{B}$ through a two-tier pyramid. Control is measured by the strongest link in its control chain (in this example 25\%). Cash flow ownership is measured as the product of ownership stakes along the control chain (in this example: $20 \% * 25 \%=5 \%$ ). In our sample, $17.4 \%$ of IPO firms apply a two-tier pyramid structure.

Table 2 shows the CEO/owner-manager owns 39.2\% of post-IPO cash flow rights and controls $44.3 \%$ of post-IPO votes, on average. Conditional on a CEO/ownermanager owning stock in the IPO firm, he owns $42.5 \%$ of post-IPO cash flow rights and controls $48 \%$ of post-IPO votes. This is much higher than CEO ownership in U.S. IPO firms $^{5}$. When we compute the votes per cash flow right $(\mathrm{V} / \mathrm{C})$, we observe that CEOs/owner-managers of French IPO firms have 1.14 votes per post-IPO cash flow right. This reflects the use of the double voting rule and two-tier pyramiding structures and has the potential to increase the conflict between the owner-manager and minority shareholders because the owner-manager may maintain a lock on control while holding fewer cash flow rights than voting rights. For instance, CEOs in IPO firms that adopt two-tier pyramiding structures own $29.9 \%$ of cash flow rights, but exercise $42.5 \%$ of post-IPO votes, on average. Other significant post-IPO shareholders are inside directors (other than the owner-manager), who own $12.1 \%$ of post-IPO shares, outside directors owning $4.6 \%$ of post-IPO stock, and venture capitalists that own $8.9 \%$ of post-IPO shares, on average.

\subsubsection{Power of the owner-manager}

\footnotetext{
${ }^{5}$ Harjoto and Garen (2005) report that the mean CEO stake in U.S. IPO firms during 1996-1997 amounts to $16.2 \%$ of shares directly after the IPO.
} 
In this study, we employ a game-theoretic power index developed by Banzhaf (1965). This Z-index captures the probability that the outcome of the voting process changes when the owner-manager changes his mind unilaterally, assuming that all vectors of votes are equally likely. The $Z$-index yields similar results as Shapley values, but has the advantage that it more easily incorporates the effects of pyramid structures (Crama et al., 1999). Based on Crama et al. (1999), we illustrate the computation of the $Z$-index in two simple cases.

[Please insert Figure 1 about here]

In Panel A of Figure 1, we assume there is one proposal put to the shareholders' meeting on which two shareholders (S1 with 3 votes, S2 with 2 votes) have to vote 'yes' or 'no'. If we assume that the votes are not correlated, there are $4\left(2^{2}\right)$ possible voting series. There are two voting series where S1 changes his vote while S2 does not. On both occasions, the final outcome of the voting game changes. Conversely, when S2 changes his vote, the final outcome does not change. This reflects that $\mathrm{S} 1$ has full control over the company and S2 can therefore not influence the outcome of the voting game. The Zindex is determined as the ratio between the number of changes in the final outcome triggered by the change of vote of an individual shareholder and the total number of changes in the final outcome triggered by all shareholders. In this example, there are two changes in the final outcome both induced by voting changes of $\mathrm{S} 1$. The $Z$-index thus equals $100 \%(2 / 2)$ for $\mathrm{S} 1$ and $0 \%(0 / 2)$ for $\mathrm{S} 2$.

Panel B of Figure 1 shows the second example, with 4 shareholders and $16\left(2^{4}\right)$ possible voting series. The $Z$-index now equals $50 \%$ for S1 with 3 votes and $16.67 \%$ for each of the other three shareholders with 2 votes. We take into account the effect of pyramids by first playing the voting game with the shareholders of the holding company and then with the shareholders of the operating company. For instance, consider the example shown in Panel B of Figure 1. Assume that S1 is a holding company owned by 
shareholder T1 with 3 votes and shareholder T2 with 2 votes. The $Z$-index of T1 equals $100 \%$ and that of T2 equals $0 \%$ at the level of the holding company (as in Panel A of Figure 1). At the level of the operating company the same results obtain as in Panel B of Figure 1 . The $Z$-index equals $50 \%$ for $\mathrm{T} 1,0 \%$ for $\mathrm{T} 2$ and $16.67 \%$ for the three other shareholders S2, S3 and S4.

We calculate the Z-index under the assumption that all existing IPO shareholders enter into the voting game (using their post-IPO voting power). The float at the IPO is constituted of a large number of small investors that are equally divided into 'yes' and 'no' voters to the proposal. When the CEO/owner-manager owns more than $50 \%$ of the post-IPO votes, he clearly has a lock on control (i.e., Z-index equals 100\%). But when the owner-manager owns less than $50 \%$ of the post-IPO votes he can still be in full control in the absence of any other large shareholders with sufficient votes to beat him in the voting process. The owner-manager only shares power in case other large shareholders alone or together are able to successfully oppose him in the voting game. We therefore argue that the $Z$-index better measures the power of the owner-manager than the percentage of votes controlled by the owner-manager. Table 2 (Panel B) shows that the unconditional average of the $Z$-index of the owner-manager equals $61.7 \%$ with a conditional average of $66.8 \%$. This shows that, on average, the owner-manager derives more power from his post-IPO votes because of a more fragmented ownership structure among the other shareholders. We also divide the $Z$-index by the cash flow ownership of the owner-manager to determine power per cash flow right. The average (median) power per cash flow right equals 1.41 (1.44) power units per cash flow right.

\subsubsection{Differences across industries}

Table 3 shows the average and median values of selected key variables per industry. We test for differences in means using a $t$-test and for differences in medians using the Wilcoxon/Mann-Whitney test. 
[Please insert Table 3 about here]

We find that non-financial firms have higher market-to-book ratios than manufacturing firms. These industries do not exhibit any other statistically significant differences. The technology companies report less plant, property and equipment on their balance sheets and sell more shares to the public than companies that belong to the other two industry groups. Technology companies also have a higher market-to-book ratio than companies from the manufacturing industry. In addition, $\mathrm{CEO} /$ owner-managers of technology companies own less cash flow rights and voting rights (and thus power) than their counterparts at manufacturing and non-financial services firms.

The differences between the technology firms and the other firms can partially be attributed to the fact that Nouveau Marché companies dominate the technology sample (61\% of technology companies list on that market segment). Nouveau Marché companies are subject to listing requirements that require companies to sell at least $20 \%$ of their shares in the IPO, whereas companies that go public on the Second Marché only have to sell at least $10 \%$ of their shares in the IPO. Additionally, for Nouveau Marché companies at least half of the IPO shares must be newly issued, the shares must be held by at least 100 different shareholders, and IPO proceeds must be larger than $€ 5$ million. These rules do not apply to Second Marché companies. This implies that Nouveau Marché companies need to sell more shares to the public and tend to have a more dispersed post-IPO ownership structure than Second Marché companies. As a result, CEO/owner-managers of Nouveau Marché companies own less post-IPO shares and votes than Second Marché companies. This suggest that it is important to control for industry as well as listing venue in our regression analyses.

\subsubsection{Shareholder agreements}


Table 4 describes the provisions contained in shareholder agreements (pactes d'actionnaires) between the CEO/owner-manager and other pre-IPO shareholders. The median pact in our sample lasts for 5 years with a minimum of 1 year and a maximum of 20 years. In total $79(26.4 \%)$ IPO firms disclose information regarding shareholder agreements in their prospectus. We are able to retrieve the provisions contained in the agreement for 74 IPO firms. The pre-emptive buying rights (droit de préemption) are most common. These pre-emptive buying rights give the priority buying right to contracting shareholders if one of the other contracting shareholders wants to sell (part of) his shares. Another frequently observed provision relates to concerted action (action de concert), which entails that contracting shareholders agree to meet before the general meeting to discuss strategic issues. About $17 \%$ of contracting shareholders agree to jointly retain a majority control block (pacte de majorité) of at least $50 \%$ of post-IPO votes in the firm. Joint exit (droit de sortie) is a provision that forces contracting (minority) shareholders to sell on the same terms as the controlling shareholder in case the latter decides to accept a tender offer for his shares. Provisions regarding board representation (clause de répartition) prescribe board composition between the contracting shareholders and are made in $16.2 \%$ of shareholder agreements.

[Please insert Table 4 about here]

Table 4 also shows that inside directors (other than the CEO) are the most common contracting parties, followed by venture capitalists and industrial companies. All contracting shareholders (including the CEO/owner-manager) own an average (median) of $74.3 \%(78.4 \%)$ of post-IPO votes.

\subsection{Multiple regression analysis}


The data are analyzed using multiple regression analysis. Throughout the paper, we use White (1980) heteroscedastic-consistent standard errors to compute $t$-statistics. We use the natural logarithm of the market-to-book ratio of equity as our proxy for firm value. The market-to-book ratio reflects the valuation of the firm from the perspective of the minority shareholder who does not enjoy any private benefits of control (La Porta et al., 2002). Market-to-book ratio is censored at its $5^{\text {th }}$ and $95^{\text {th }}$ percentile. This resolves potential problems with extreme observations. In sensitivity analyses, we employ alternative dependent variables such as the price-to-book ratio and the price-to-cash flow ratio. We employ several control variables in our regressions, such as the natural logarithm of sales to control for differences in firm size. We include company age in the regressions as an ex-ante proxy for risk and the cash flow margin to control for differences in profitability between IPO firms. Cash flow margin is censored at its $5^{\text {th }}$ and $95^{\text {th }}$ percentile. We control for differences in asset tangibility by including plant, property and equipment (expressed as a percentage of total assets) into the regression model. We also incorporate time fixed effects (i.e., a set of year dummies for the years 1993 to 1998) and two industry dummies (for technology and manufacturing firms with nonfinancial services firms as a reference category). This is important given the differences between high-technology companies vis-à-vis companies from the non-financial services and manufacturing industry (see section 3.2.4). We include a dummy indicating whether the IPO took place on the Nouveau Marché to control for potential differences in listing venue. Table 5 shows the definition of the variables included in the regressions.

[Please insert Table 5 about here]

We regress firm value on the post-IPO cash flow ownership of the ownermanager to test Hypothesis 1a. We also include the square of post-IPO cash flow ownership of the owner-manager to examine a possible non-linear relation between cash flow ownership of the owner-manager and IPO firm value (Hypothesis 1b). To test 
Hypothesis 2 we introduce the votes per cash flow right variable, defined as the ratio of voting to cash flow rights in the hands of the owner-manager, in the regression analysis. Hypothesis 3 is tested by including a dummy variable that takes on the value one if the $\mathrm{CEO} /$ owner-manger has entered into a shareholder agreement and zero otherwise. We include the power per cash flow right variable, defined as the $Z$-index of post-IPO power of the owner-manager divided by his cash flow ownership, in the regression to test Hypothesis 4. We compute variance inflation factors to determine whether multicollinearity is a significant problem. With two exceptions all variance inflation factors of the independent variables are lower than ten ${ }^{6}$. This indicates that multicollinearity is not a severe problem in our analysis.

\section{Empirical results}

\subsection{Ownership and control}

Table 6 presents the results of the regression analyses used to test the hypotheses. In Model (1) we regress IPO firm value, as measured by the market-to-book ratio, on the cash flow ownership of the owner-manager and its square. We find that cash flow ownership of the owner-manager is significantly related to IPO firm value $(p<0.05)$ in the manner predicted by Hypothesis 1a. However, this relation is curvilinear as the coefficient on the square of the cash flow ownership of the owner-manager is significantly negative $(p<0.10)$. This supports Hypothesis $1 \mathrm{~b}$. Our findings suggest that, ceteris paribus, IPO firm value increases until the post-IPO cash flow ownership of the owner-manager reaches $56.7 \%$ (the inflection point) and declines beyond that. This inflection point is higher than the 40 to $50 \%$ that McConnell and Servaes (1990) report

\footnotetext{
${ }^{6}$ Variance inflation factors (VIFs) in excess of 10 suggest multicollinearity problems. The highest inflation factors are inherently associated with cash flow ownership of the CEO/owner-manager (VIF=19.56) and its square $(\mathrm{VIF}=18.29)$.
} 
for the United States ${ }^{7}$. However, their study does not consider IPO firms. Moreover, the higher inflection point in France is consistent with the model of Wu and Wang (2004) that predicts higher value-maximizing levels of inside ownership when private benefits are large (such as in France) compared to situations where private benefits are small (in countries with strong legal systems such as the United States).

Model (2) adds the owner-manager's votes per cash flow right as an independent variable. This captures the extent to which the owner-manager has separated his voting and cash flow rights. In support of Hypothesis 2 we find a negative association between the votes per cash flow right variable and IPO firm value $(p<0.05)$. The inflection point equals $54.1 \%$. Model (3) incorporates a dummy that equals one if the owner-manager has entered into a shareholder agreement with other pre-IPO owners. We find that the existence of a shareholder agreement is positively related to firm value $(p<0.05)$, consistent with Hypothesis 3 and recent theoretical work of Chemla et al. (2002). After inclusion of the shareholder agreement dummy, the inflection point increases to $65 \%$. We argue that the presence of shareholder agreements enables the owner-manager to own more stock in the company without investors viewing him as becoming entrenched because he is sharing control with other pre-IPO shareholders.

Next, Model (4) includes the power per cash flow right of the owner-manager. We find strong support for Hypothesis 4. The power per cash flow right variable is negatively related to IPO firm value and its regression coefficient is highly significant $(p<0.01)$. The inflection point equals $52.5 \%$. This finding is consistent with Thomsen et al. (2005). They show that there is a discount associated with a high degree ownership concentration in Continental Europe.

[Please insert Table 6 about here]

\footnotetext{
${ }^{7}$ We should be careful in comparing our results with those of other studies. Morck, Shleifer and Vishny (1988), McConnell and Servaes (1990) and Short and Keasey (1999) all investigate samples of larger
} 
In Model (5) we jointly analyze the cash flow ownership of the owner-manager and its square, the votes per cash flow right, shareholder agreements and the power per cash flow right. In accordance with Hypotheses $1 \mathrm{a}$ and $1 \mathrm{~b}$, we find that the cash flow ownership of the owner-manager is positively related to IPO firm value $(p<0.01)$ and that this relationship is curvilinear $(p<0.05)$. Again, we find that the presence of a shareholder agreement $(p<0.05)$ is positively related to IPO firm value. The power per cash flow right variable is negatively related to IPO firm value $(p<0.01)$. Although the negative relation between the votes per cash flow right and IPO firm value persists, it lacks statistical significance at conventional levels. The inflection point in Model (5) equals $55.3 \%$. Our results show that incentive and entrenchment effects can go together and that shareholder agreements are positively related to IPO firm value.

\subsection{Robustness checks}

One possible problem with our analysis in the previous section is that we did not take endogeneity between ownership and value into account (Demsetz and Lehn, 1985; Demsetz and Villalonga, 2001). We first test for endogeneity using using the DurbinWu-Hausman test as augmented by Davidson and MacKinnon (1993). This test can be formed by including the residuals of each endogenous right-hand side variable, as a function of all exogenous variables, in a regression of the original model to test whether the coefficients on the residuals are significantly different from zero. We find that firm value measured by the market-to-book ratio is not endogenous to CEO cash flow ownership $(p=0.79)^{8}$. We also checked whether firm value is endogeneous to the power

\footnotetext{
publicly traded companies in the U.S. and the U.K. As Kole (1995) shows differences in the size of sample firms can lead to different findings in these type of studies.

${ }^{8}$ Although the test rejects endogeneity, we have used the instrumental variables (2SLS) technique to address a potential endogeneity problem. We use two valid instruments for CEO cash flow ownership: $\mathrm{CEO}$ founder status (a dummy variable that equals one if the $\mathrm{CEO} /$ owner-manager founded the company) and CEO tenure (the number of years the CEO/owner-manager has been employed by the company). We find that the coefficient on the cash flow ownership held by the CEO/owner-manager variable continues to be significantly positive $(p<0.05)$ in the second stage regression. This suggests that endogeneity is not a major problem in our analysis.
} 
of the CEO as measured by the $Z$-index. The Durbin-Wu-Hausman test suggests it is not $(p=0.85)$.

Next, we re-estimate all regressions using pre-IPO rather than post-IPO ownership. Pre-IPO ownership is by definition not determined by selling behavior at the IPO. We find similar relationships between pre-IPO ownership variables and firm value as we did for post-IPO ownership variables and firm value (results not tabulated).

To further check the robustness of our findings, we re-estimate Model (5) of Table 6 without time fixed effects and without the votes per cash flow right variable that was insignificant in previous regressions. Table 7 shows the results. We find qualitatively similar results. Then we divide the sample into 201 Second Marché IPO firms and 98 Nouveau Marché IPO firms. As a natural consequence, dividing the sample into two subsets reduces the power of the tests.

[Please insert Table 7 about here]

We find that the curvilinear relationship between cash flow ownership and IPO firm value is invariant to listing venue. However, cash flow ownership squared is only significantly related to firm value for the Nouveau Marché sample. The shareholder agreement dummy and the power per cash flow right variable are only significantly related to IPO firm value for the Second Marché sample. This suggests that private benefits of control may play a more important role for this group. We also use alternative dependent variables. We re-estimate Model (5) of Table 6 using the price-to-book ratio as the dependent variable and without the votes per cash flow right variable. We find that our findings are invariant to using this alternative dependent variable. We also use the price-to-cash flow ratio as an alternative dependent variable. Again, qualitatively similar results are found. We also re-estimate Model (5) of Table 6 by substituting power per cash flow right with a dummy variable that takes on the value one if the $Z$-index equals $100 \%$. This measures whether the owner-manager is in full control over the IPO firm. 
We find that the coefficient on this dummy equals $-0.257(p<0.01)$. For reasons of brevity, these results are not tabulated.

We have used the market-to-book ratio of assets as an alternative dependent variable. The market-to-book ratio of assets is computed as the sum of the market value of equity and the book value of debt divided by the book value of assets from the most recent financial statement included in the prospectus. We find qualitatively similar results. We have also included dummy variables that indicate the identity of nonmanagement owners in the company (venture capitalists, industrial companies and financial investors). None of the coefficients on these dummy variables is statistically significant. We argue that it is not the identity of the non-management owner that matters, but the fact that non-management owners are sufficiently powerful to oppose the owner-manager.

We have also considered other forms of the relationship between cash flow ownership and IPO firm value. For example, Morck et al. (1988) and Short and Keasey (1999) find evidence to support an incentive-entrenchment-incentive effect in the relationship between ownership and firm value. We adopt the approach of Short and Keasey (1999) and re-estimate our regression models using a cubic form of the relationship (i.e., adding the cube of the cash flow ownership of the owner-manager in the regressions). We find that the coefficient on the cube of cash flow ownership is not significant in any of the regressions (not reported). Overall, our findings suggest that the results are not spurious but instead reflect a definite structure within the data that is supportive of Hypotheses 1a, 1b, 3 and 4.

\subsection{Private benefits of control}

Throughout our analysis we have assumed that an important motivation for managers to entrench is the presence of large private benefits of control. But what are these private benefits of control? Although they are difficult to measure empirically, we attempt to 
develop proxies for private benefits of control. We divide the sample into Second Marché and Nouveau Marché companies to investigate whether there are any differences in private benefits of control between these two markets. Table 8 shows the results of our univariate tests for the entire sample and the two subsamples. We first look at nepotism. If control resides with owner-managers they may use their controlling position to appoint family members (by blood or marriage) as non-executive directors. We find the percentage of family directors is significantly larger when the owner-manager is in full control. In particular, we report that, on average, family directors occupy 27 [14.6] percent of board seats in Second Marché [Nouveau Marché] companies with full ownermanager control $(Z$-index=1) vis-à-vis 7.8 [5.8] percent in partially-controlled Second Marché [Nouveau Marché] companies (Z-index $<1)$.

In France, companies can choose whether they adopt a second-tier or a one-tier board structure. The one-tier board structure combines the positions of CEO and chairman into that of Président Directeur Général (PDG). According to French corporate law, the PDG is selected by the board, which in turn is then appointed by shareholders. In practice, it is often the PDG that appoints the board, a choice which is then ratified by the shareholders. The second-tier structure consists of a management board (Directoire) and a supervisory board (Conseil de Surveillance). Supervisory board members are outside directors that are appointed and dismissed by the shareholders' meeting. The CEO can exert little influence on supervisory board appointments. We expect that owner-managers that are in full control are less likely to adopt the two-tier board because this board structure separates the positions of CEO and chairman and allows for less influence on board appointments. Accordingly, we find that the two-tier board structure is adopted by 5.1 [2.5] percent of Second Marché [Nouveau Marché] companies with full owner-manager control $(Z$-index=1) vis-à-vis 22.1 [15.5] percent in partially-controlled Second Marché [Nouveau Marché] companies (Z-index<1), on average. 
We use board compensation as a measure for self-dealing. In France, companies are not required to disclose cash compensation for individual directors. We therefore take the aggregate cash compensation from the year before the IPO and divide this by the number of board seats. We find that the average board member of Second Marché [Nouveau Marché] companies earns $€ 17,200$ [€13,500] less cash compensation when the owner-manager is in full control $(Z$-index $=1)$ than when the owner-manager has to share control with other shareholders $(Z$-index $<1)$. This suggests that owner-managers with full control do not use their power to extract excessive cash compensation. If anything, owner-managers with full control earn less cash compensation than owner-manages with partial control.

[Please insert Table 8 about here]

The lock on control may also be motivated by status and prestige. We capture this by looking at whether the last name of the owner-manager and firm name are the same. We find that only a few owner-managers of Nouveau Marché companies give their family name to the firm. However, we report that 25.4 percent of Second Marché companies with full owner-manager control $(Z$-index $=1)$ have the same name as the family name of the owner-manager versus 6 percent in partially-controlled Second Marché companies $(Z$-index $<1)$. This suggests that owner-managers derive private benefits from being in control of a company that carries their family name.

As a final point, we look at whether the firm is a regional business. A regional business is defined as a firm headquartered outside Paris, Lyon, Marseille and Lille (the four largest cities with more than one million inhabitants). We argue that the ownermanager of a regional business derives status from being an important employer in a local community. This measure is based on Ehrhardt and Nowak (2003). They find that German family-owned IPO firms are more likely to use dual class shares when they are important employers in a small town. We find that 51.7 [42.5] percent of Second Marché 
[Nouveau Marché] companies with full owner-manager control $(Z$-index=1) are regional businesses vis-à-vis 37.4 [29.3] percent of partially-controlled Second Marché [Nouveau Marché] companies (Z-index $<1$ ), on average. However, the difference is not significant for the Nouveau Marché. Overall, we conclude that, consistent with Hypothesis 5, private benefits of control are greater for owner-managers that have decided to keep full control over the IPO firm, especially for Second Marché IPO firms.

\section{Summary and conclusions}

Going public often creates an agency conflict between the owner-manager and minority shareholders. This problem is especially severe in countries with poor legal protection, such as France. We examine the controlling position of owner-managers in French IPO firms and disentangle their cash flow rights and voting power. We relate both of them to IPO firm value.

We find that the relationship between firm value and the owner-manager's postIPO cash flow ownership is positive when the owner-manager is not in full control. As his cash flow ownership increases, the owner-manager will bear more of the wealth consequences of enjoying private benefits and he will have incentives to reduce them. However, for higher levels of cash flow ownership, entrenchment effects start to outweigh the incentive effect. We find that investors anticipate the increased agency conflict associated with a lock on control, and lower firm value when the owner-manager is more powerful. The inflection point at which cash flow ownership becomes negatively related to firm value varies between $50 \%$ and $60 \%$, depending on the model specification.

To disentangle incentive and entrenchment effects, we focus on the post-IPO power of the owner-manager vis-à-vis other shareholders, which we measure using Banzhaf's (1965) Z-index, a game-theoretic power index. We find that that ownermanager's power per cash flow right is negatively related to IPO firm value. This 
entrenchment effect is invariant to the use of alternative measures of IPO firm value and represents the price of power. Moreover, we refine our analysis of power in the IPO firm by examining shareholder agreements. By reaching an agreement with other pre-IPO shareholders, the owner-manager commits to reducing his private benefit consumption. As predicted by recent theoretical work of Chemla et al. (2002), we find that the presence of shareholder agreements is positively related to IPO firm value.

The entrenchment effect provides indirect evidence of expropriation of minority shareholders by the owner-manager. But what are these private benefits of control? Several recent studies, such as Yermack (2004) and Rajan and Wulf (2004), have started to answer this question. We add to this literature and show that full control of the ownermanager correlates with board appointments of family members (nepotism) and the use of a one-tier rather than two-tier board structure (power and prestige). This suggests that the owner-manager increases his power over the board selection process. We also find that the owner-manager retains full control when the firm carries his family name and when the firm is an important employer in its region (status). These results are consistent with the idea that owner-managers of IPO firms keep in control if they derive large nonpecuniary private benefits from their controlling positions. As predicted by agency theory, minority shareholders price-protect themselves against this potential value loss by reducing the price they are willing to pay for the shares in the IPO. 


\section{References}

Alcouffe, C., 2000, "Judges and CEOs: French Aspects of Corporate Governance", European Journal of Law and Economics 9, 127-144.

Anderson, R.C. and D.M. Reeb, 2003, “Who Monitors the Family?”, Working paper, American University and University of Alabama.

Banzhaf, J.F, 1965, “Weighted Voting Doesn't Work: A Mathematical Analysis", Rutgers Law Review 19, 317-343.

Barth, E., T. Gulbrandsen and P. Schønea, 2005, "Family Ownership and Productivity: The Role of Owner-Management" Journal of Corporate Finance, forthcoming.

Bebchuk, L.A., 1999, A Rent-Protection Theory of Corporate Ownership and Control, Working paper, NBER.

Bebchuk, L., R. Kraakman and G. Triantis, 2000, "Stock Pyramids, Cross-Ownership, and Dual Class Equity: The Creation and Agency Costs of Separating Control from Cash Flow Rights", University of Chicago Press: Chicago.

Bennedsen, M. and D. Wolfenzon, 2000, “The Balance of Power in Closely Held Corporations", Journal of Financial Economics 58, 113-139.

Chemla, G., M.A. Habib and A.P. Ljungqvist, 2002, An Analysis of Shareholder Agreements, Working paper, University of Zurich and New York University.

Coffee, J., 2001, Do Norms Matter?: A Cross-Country Examination of the Private Benefits of Control, Working paper, Columbia Law School.

Crama, Y., L. Leruth, L. Renneboog and J.P. Urbain, 1999, Corporate Governance Structures, Control and Performance in European Markets: A Tale of Two Systems, Working paper, Tilburg University.

Davidson, R and J.G. MacKinnon, 1993, "Estimation and Inference in Econometrics", Oxford University Press: New York.

Demsetz, H. and K. Lehn, 1985, “The Structure of Corporate Ownership: Causes and Consequences", Journal of Political Economy 93, 1155-1177. 
Demsetz, H. and B. Villalonga, 2001, "Ownership Structure and Corporate Performance", Journal of Corporate Finance 7, 209-233.

Derrien, F. and K.L. Womack, 2003, “Auctions versus Book-Building and the Control of Underpricing in Hot IPO Markets”, Review of Financial Studies 16, 31-61.

Dyck, A. and L. Zingales, 2004, "Private Benefits of Control: An International Comparison", Journal of Finance 59, 537-600.

Ehrhardt, O. and E. Nowak, 2003, Private Benefits and Minority Shareholder Expropriation, Working paper, Humboldt University and University of Southern Switzerland Lugano.

Fanto, J.A., 1998, "The Role of Corporate Law in French Corporate Governance", Cornell International Law Journal 31, 31-91.

Field, L.C. and J.M. Karpoff, 2002, “Takeover Defenses at IPO Firms”, Journal of Finance 57, 1857-1889.

Gomes, A. and W. Novaes, 2001, Sharing of Control as a Corporate Governance Mechanism, Working paper, University of Pennsylvania and University of Washington.

Grossman, S.J. and O.D. Hart, 1988, “One Share-One Vote and the Market for Corporate Control", Journal of Financial Economics 20, 175-202.

Harjoto, M. and J. Garen, 2005, "Inside Ownership Beyond the IPO: The Evolution of Corporate Ownership Concentration", Journal of Corporate Finance forthcoming.

Jensen, M.C. and W.H. Meckling, 1976, "Theory of the Firm: Managerial Behavior, Agency Costs and Capital Structure", Journal of Financial Economics 3, 305360.

Johnson, S., R. La Porta, F. Lopez-de-Silanes and A. Shleifer, 2000, “Tunneling”, American Economic Review 90, 22-27.

Kole, S.R., 1995, “Measuring Managerial Equity Ownership: A Comparison of Sources of Ownership Data", Journal of Corporate Finance 1, 413-435. 
La Porta, R., F. Lopez-de-Silanes and A. Shleifer, 1999, “Corporate Ownership Around the World", Journal of Finance 54, 471-517.

La Porta, R., F. Lopez-de-Silanes, A. Shleifer and R.W. Vishny, 2002, "Investor Protection and Corporate Valuation", Journal of Finance 57, 1147-1170.

McConnell, J.J. and H. Servaes, 1990, “Additional Evidence on Equity Ownership and Corporate Value", Journal of Financial Economics 27, 595-612.

Morck, R. , A. Shleifer and R.W. Vishny, 1988, "Management Ownership and Market Valuation", Journal of Financial Economics 20, 293-315.

Nenova, T., 2003, “The Value of Corporate Voting Rights and Control: A Cross-Country Analysis", Journal of Financial Economics 68, 325-351.

Rajan, R.G. and J. Wulf, 2004, Are Perks Purely Managerial Excess?, Working paper, University of Pennsylvania.

Short, H. and K. Keasey, 1999, "Managerial Ownership and the Performance of Firms: Evidence from the UK", Journal of Corporate Finance 5, 79-101.

Smart, S.B. and C.J. Zutter, 2003, "Control as a Motivation for Underpricing: A Comparison of Dual- and Single-class IPOs", Journal of Financial Economics $69,85-110$.

Stulz, R.M., 1988, "Managerial Control of Voting Rights: Financing Policies and the Market for Corporate Control”, Journal of Financial Economics 20, 25-54.

Thomsen, S., T. Pedersen, H.K. Kvist, 2004, Blockholder Ownership: Effects on Firm Value in Market and Control Based Governance Systems, Working paper, Copenhagen Business Shool.

White, H., 1980, “A Heteroskedasticity-Consistent Covariance Matrix Estimator and a Direct Test for Heteroskedasticity", Econometrica 48, 721-746.

Wu, X. and Z. Wang, 2004, "Equity Financing in a Myers-Majluf Framework with Private Benefits of Control", Journal of Corporate Finance, forthcoming.

Yermack, D., 2004, Flights of Fancy: Corporate Jets, CEO Perquisites, and Inferior Shareholder Returns, Working paper, New York University. 
Figure 1: Computing the $Z$-index

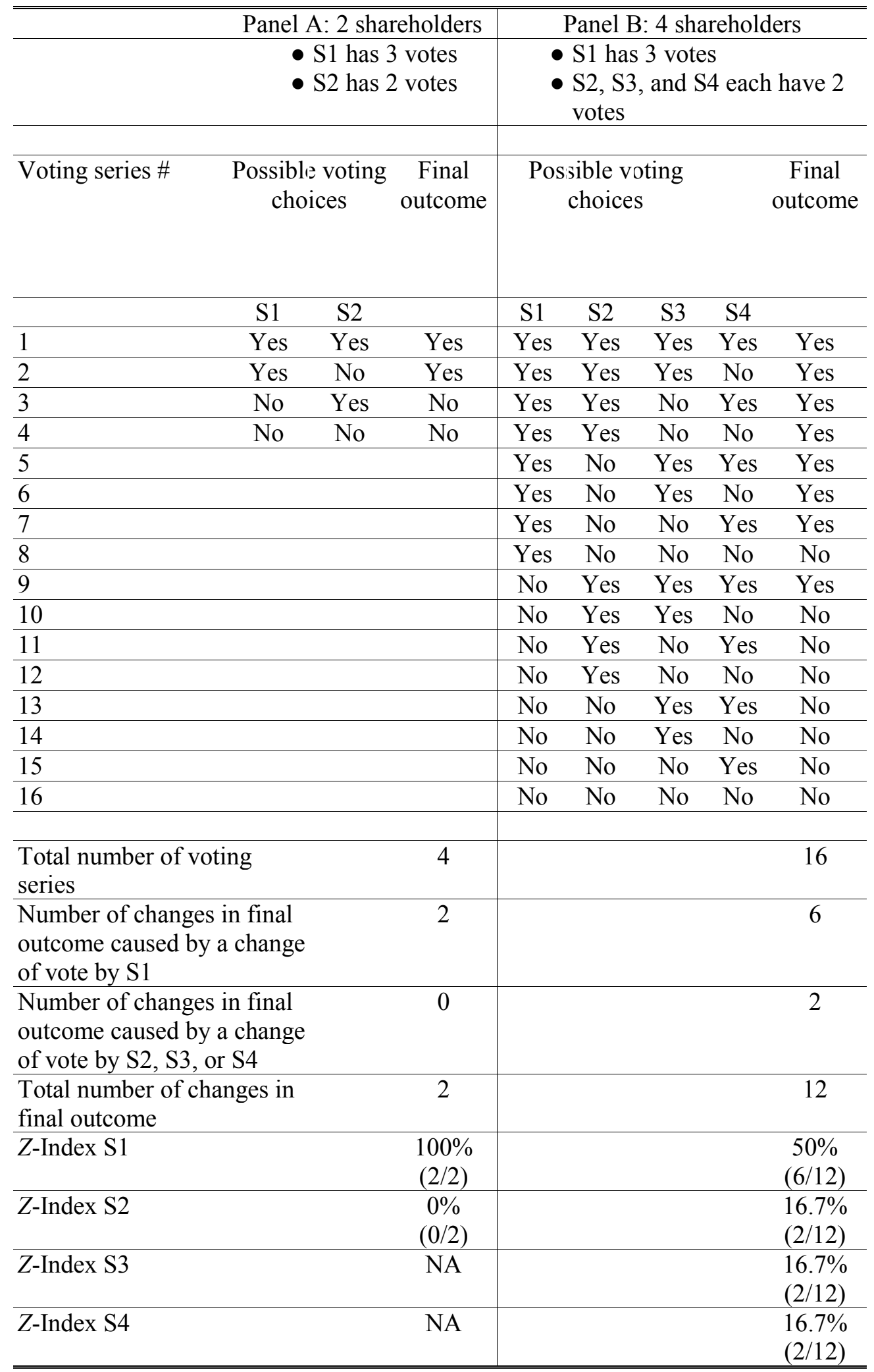




\section{Table 1: Firm and offer characteristics}

The sample consists of 299 French IPO firms from January 1993 to December 1999. Market value is measured as the number of shares outstanding after the IPO times the closing price on the first trading day (in million $€$ ). Proceeds are defined as the number of shares offered to the public times the final offer price (in million $€$ ). Shares sold to the public is computed as the number of shares that are offered in the IPO divided by the number of shares outstanding after the IPO. First-day return (underpricing) is the percentage difference between the closing price on the first day of trading and the final offer price. Sales pertain to the last 12 month period reported in the prospectus. Cash flow margin is the ratio of earnings before interest, taxes, depreciation, amortization (EBITDA) and provision allowances to sales for the last 12 months reported in the prospectus. Cash flow margin is censored at its $5^{\text {th }}$ and $95^{\text {th }}$ percentile (i.e., all values below the $5^{\text {th }}$ percentile are replaced with the value of the $5^{\text {th }}$ percentile, while all values above the $95^{\text {th }}$ percentile are substituted with the value of the $95^{\text {th }}$ percentile). Plant, property and equipment is taken from the last pre-IPO balance sheet, or when available from a later interim balance sheet as disclosed in the prospectus. It is expressed as a percentage of total assets. Company age is the difference between the IPO year and the founding year in the prospectus. Market-to-book ratio of equity is the ratio of the market value on the first day of trade and the sum of the proceeds from the newly issued shares and the book value of equity from the last pre-IPO financial statement, or when available from a later interim report included in the prospectus. Market-to-book ratio of equity is censored at its $5^{\text {th }}$ and $95^{\text {th }}$ percentile. Price-to-book ratio is the ratio of the preliminary offer value to the pre-IPO book value of equity from the last pre-IPO financial statement, or when available from a later interim report included in the prospectus. The preliminary offer value equals the number of preIPO shares times the minimum tender price (in case of auctioned IPOs), the midpoint of the price range (in case of bookbuilt IPOs) or the fixed-offer price (in case of fixed-price offerings). Price-to-cash flow ratio equals the ratio between the preliminary offer value and the sum of earnings before interest, taxes, depreciation, amortization (EBITDA) and provision allowances for the last 12 month period reported in the prospectus.

\begin{tabular}{lccccccc}
\hline \hline Variable & Mean & Min & \multicolumn{3}{c}{ Percentiles } & Max & Std.dev. \\
\cline { 3 - 6 } & & & $25^{\text {th }}$ & $50^{\text {th }}$ & $75^{\text {th }}$ & & \\
\hline Market value (million $€$ ) & 76.01 & 10.70 & 24.09 & 40.84 & 87.24 & 827.00 & 97.96 \\
Proceeds (million $€$ ) & 13.52 & 1.31 & 4.68 & 7.36 & 15.06 & 103.93 & 16.72 \\
Shares sold to public (\%) & 22.19 & 3.51 & 14.28 & 20.00 & 28.63 & 71.75 & 10.61 \\
First-day return (\%) & 14.37 & -26.99 & 0.00 & 6.90 & 19.95 & 136.30 & 23.85 \\
Sales (million $€$ ) & 64.35 & 0.20 & 11.72 & 24.77 & 66.95 & 942.52 & 115.39 \\
Cash flow margin (\%) & 16.95 & 2.12 & 10.69 & 15.52 & 21.63 & 39.12 & 9.14 \\
Plant, property and equipment (\%) & 17.89 & 0.21 & 5.21 & 13.46 & 25.38 & 84.55 & 16.04 \\
Company age (years) & 27.21 & 1.00 & 9.00 & 16.00 & 28.50 & 250.00 & 33.47 \\
Market-to-book ratio & 4.45 & 1.45 & 2.70 & 3.65 & 5.06 & 11.62 & 2.66 \\
Price-to-book ratio & 6.85 & 1.36 & 2.92 & 4.95 & 8.57 & 21.50 & 5.40 \\
Price-to-cash flow ratio & 12.11 & 1.90 & 5.27 & 8.51 & 15.12 & 40.23 & 9.96 \\
\hline \hline
\end{tabular}


Table 2: Post-IPO cash flow ownership and voting structure

This table shows the average, median, minimum and maximum cash flow ownership (Panel A) and voting (Panel B) percentages for different categories of shareholders. The shares and votes may be held directly and indirectly via a pyramiding structure. Ownership and voting percentages are averaged unconditional and conditional on that particular category of shareholder being present ( $\mathrm{N}$ denotes the number of IPO firms in which that category of shareholder owns stock). Cash flow ownership and voting structure are different because of pyramiding and/or double voting systems. The Président Directeur Général (PDG) in the one-tier board structure and the Président du Directoire in the two-tier structure are classified as Chief Executive Officer (CEO). In our sample, there are 33 IPO firms that apply the two-tier board structure. Inside directors are board members that are current managers of the company (other than the CEO/owner-manager). Outside directors are board members without day-to-day management responsibility. Institutional investors include banks, insurance companies and pension funds. The $Z$-index measures the power of the CEO/owner-manager versus other shareholders in a voting game (see Figure 1). Power per cash flow right $(\mathrm{P} / \mathrm{C})$ is the ratio of the $Z$-index and the cash flow ownership of the owner-manager. V/C denotes votes per cash flow right. NA denotes not applicable.

\begin{tabular}{|c|c|c|c|c|c|c|c|c|c|c|c|}
\hline \multirow[t]{2}{*}{ Shareholder identity } & \multicolumn{5}{|c|}{ Unconditional } & \multicolumn{6}{|c|}{ Conditional } \\
\hline & Average & Median & Std.dev. & Min. & Max. & Average & Median & Std.dev. & Min. & Max. & $\mathrm{N}$ \\
\hline CEO/owner-manager & 39.23 & 38.75 & 27.43 & 0.00 & 89.49 & 42.50 & 43.11 & 26.00 & 0.01 & 89.49 & 276 \\
\hline Inside directors & 12.09 & 4.92 & 15.43 & 0.00 & 79.95 & 16.97 & 12.47 & 15.86 & 0.01 & 79.95 & 213 \\
\hline Outside directors & 4.57 & 0.00 & 11.88 & 0.00 & 67.11 & 11.88 & 3.85 & 16.77 & 0.01 & 67.11 & 103 \\
\hline Venture capitalists & 8.86 & 0.00 & 14.91 & 0.00 & 72.40 & 19.19 & 14.26 & 16.85 & 0.49 & 72.40 & 138 \\
\hline Industrial companies & 5.21 & 0.00 & 16.36 & 0.00 & 86.30 & 32.47 & 20.13 & 28.17 & 0.53 & 86.3 & 48 \\
\hline Institutional investors & 3.36 & 0.00 & 10.73 & 0.00 & 83.07 & 16.22 & 11.41 & 18.73 & 0.23 & 83.07 & 62 \\
\hline
\end{tabular}

Panel B: Voting rights

\begin{tabular}{|c|c|c|c|c|c|c|c|c|c|c|c|c|}
\hline \multirow[t]{2}{*}{ Shareholder identity } & \multicolumn{5}{|c|}{ Unconditional } & \multicolumn{7}{|c|}{ Conditional } \\
\hline & Average & Median & Std.dev. & Min. & Max. & Average & Median & Std.dev. & Min. & Max. & $\mathrm{V} / \mathrm{C}$ & $\mathrm{N}$ \\
\hline CEO/owner-manager & 44.32 & 45.87 & 30.36 & 0.00 & 94.16 & 48.01 & 49.30 & 28.65 & 0.01 & 94.16 & 1.14 & 276 \\
\hline Z-index & 61.68 & 100.00 & 42.60 & 0.00 & 100.00 & 66.81 & 100.00 & 40.27 & 0.00 & 100.00 & NA & 276 \\
\hline $\mathrm{P} / \mathrm{C}$ & 1.41 & 1.44 & 0.90 & 0.00 & 5.15 & 1.53 & 1.50 & 0.84 & 0.00 & 5.15 & NA & 276 \\
\hline Inside directors & 11.91 & 3.29 & 16.35 & 0.00 & 79.95 & 16.72 & 11.16 & 17.18 & 0.01 & 79.95 & 0.96 & 213 \\
\hline Outside directors & 4.72 & 0.00 & 13.00 & 0.00 & 73.61 & 12.26 & 2.98 & 18.66 & 0.01 & 73.61 & 1.03 & 103 \\
\hline Venture capitalists & 8.65 & 0.00 & 15.51 & 0.00 & 80.39 & 18.75 & 13.10 & 18.23 & 0.18 & 80.39 & 0.94 & 138 \\
\hline Industrial companies & 5.15 & 0.00 & 16.97 & 0.00 & 91.70 & 32.09 & 17.77 & 30.70 & 0.39 & 91.70 & 0.94 & 48 \\
\hline Institutional investors & 3.28 & 0.00 & 10.97 & 0.00 & 84.38 & 15.80 & 10.09 & 19.67 & 0.01 & 84.38 & 0.95 & 62 \\
\hline
\end{tabular}




\section{Table 3: Selected key variables per industry}

This table shows the unconditional average and median [in brackets] of selected key variables per industry. Market-to-book ratio, plant, property and equipment (expressed as a percentage of total assets) and shares sold to the public (expressed as a percentage of total shares outstanding after the IPO) are defined in Table 1. Post-IPO cash flow rights and votes held by the CEO/owner-manager as well as the Z-index are defined as in Table 2. We test for differences in mean using a $t$-test and for differences in median using the Wilcoxon/Mann-Whitney test. Test statistics are reported in the last three columns [test-statistics for the Wilcoxon/Mann-Whitney test are reported in brackets]. ${ }^{*}$ significant at the $10 \%$ level; ** significant at the $5 \%$ level; ${ }^{* * *}$ significant at the $1 \%$ level.

\begin{tabular}{|c|c|c|c|c|c|c|}
\hline & $\begin{array}{l}\text { Manufacturing } \\
(\mathrm{N}=100)\end{array}$ & $\begin{array}{l}\text { Non- } \\
\text { financial } \\
\text { services } \\
(\mathrm{N}=112)\end{array}$ & $\begin{array}{l}\text { High- } \\
\text { technology } \\
(\mathrm{N}=87)\end{array}$ & $\begin{array}{l}\text { Test for } \\
\text { difference } \\
\text { manufacturing } \\
\text { and non- } \\
\text { financial } \\
\text { services }\end{array}$ & $\begin{array}{l}\text { Test for } \\
\text { difference } \\
\text { manufacturing } \\
\text { and high- } \\
\text { technology }\end{array}$ & $\begin{array}{l}\text { Test for } \\
\text { difference } \\
\text { non-financial } \\
\text { services and } \\
\text { high-technology }\end{array}$ \\
\hline Market-to-book ratio & $\begin{array}{c}3.64 \\
{[3.20]}\end{array}$ & $\begin{array}{c}4.77 \\
{[3.86]}\end{array}$ & $\begin{array}{c}4.97 \\
{[4.00]}\end{array}$ & $\begin{array}{l}3.166^{* * *} \\
{[2.707]^{* * *}}\end{array}$ & $\begin{array}{l}3.900^{* * *} \\
{[4.066]^{* * *}}\end{array}$ & $\begin{array}{l}0.492 \\
{[1.102]}\end{array}$ \\
\hline $\begin{array}{l}\text { Plant, property and equipment } \\
(\%)\end{array}$ & $\begin{array}{c}20.36 \\
{[18.10]}\end{array}$ & $\begin{array}{c}21.52 \\
{[14.94]}\end{array}$ & $\begin{array}{l}10.40 \\
{[6.84]}\end{array}$ & $\begin{array}{l}0.498 \\
{[1.349]}\end{array}$ & $\begin{array}{l}6.092^{* * *} \\
{[6.461]^{* * *}}\end{array}$ & $\begin{array}{l}4.613^{* * *} \\
{[3.972]^{* * *}}\end{array}$ \\
\hline Shares sold to public (\%) & $\begin{array}{c}21.05 \\
{[19.02]}\end{array}$ & $\begin{array}{c}20.95 \\
{[18.79]}\end{array}$ & $\begin{array}{c}24.54 \\
{[24.75]}\end{array}$ & $\begin{array}{l}0.070 \\
{[0.273]}\end{array}$ & $\begin{array}{l}2.255^{* *} \\
{[2.907]^{* * *}}\end{array}$ & $\begin{array}{l}2.515^{* * *} \\
{[2.972]^{* * *}}\end{array}$ \\
\hline $\begin{array}{l}\text { Cash flow rights } \mathrm{CEO} / \text { owner- } \\
\text { manager }\end{array}$ & $\begin{array}{c}41.91 \\
{[45.49]}\end{array}$ & $\begin{array}{c}42.97 \\
{[45.77]}\end{array}$ & $\begin{array}{c}31.32 \\
{[28.21]}\end{array}$ & $\begin{array}{l}0.268 \\
{[0.364]}\end{array}$ & $\begin{array}{l}2.668^{* * *} \\
{[2.209]^{* *}}\end{array}$ & $\begin{array}{l}3.256^{* * * *} \\
{[3.046]^{* * *}}\end{array}$ \\
\hline $\begin{array}{l}\text { Voting rights CEO/owner- } \\
\text { manager }\end{array}$ & $\begin{array}{c}46.47 \\
{[53.43]}\end{array}$ & $\begin{array}{c}49.21 \\
{[54.93]}\end{array}$ & $\begin{array}{c}35.54 \\
{[31.76]}\end{array}$ & $\begin{array}{l}0.627 \\
{[0.615]}\end{array}$ & $\begin{array}{l}2.506^{* *} \\
{[2.111]^{*}}\end{array}$ & $\begin{array}{l}3.404^{* * * *} \\
{[3.182]^{* * *}}\end{array}$ \\
\hline$Z$-index & $\begin{array}{c}63.91 \\
{[1.00]}\end{array}$ & $\begin{array}{l}67.02 \\
{[1.00]}\end{array}$ & $\begin{array}{c}52.19 \\
{[33.00]}\end{array}$ & $\begin{array}{l}0.532 \\
{[0.392]}\end{array}$ & $\begin{array}{l}1.842^{*} \\
{[1.305]}\end{array}$ & $\begin{array}{l}2.564^{* * *} \\
{[2.289]^{* *}}\end{array}$ \\
\hline
\end{tabular}




\section{Table 4: Shareholder agreements}

The sample consists of 79 IPO firms that disclose information regarding shareholder agreements (pactes d'actionnaires) between the CEO/owner-manager and other pre-IPO shareholders. The table shows the provisions included in the shareholder agreement (available for 74 IPO firms) and the other contracting shareholders (other than the $\mathrm{CEO}$ /owner-manager). Please note that a shareholder agreement may contain more than one provision and may be signed by more than two contracting parties (this explains why the columns do not add up to $100 \%$ ).

\begin{tabular}{lr}
\hline \hline Provisions in shareholder agreements & \\
\hline Preemptive buying right & $71.62 \%$ \\
Concerted action & $45.95 \%$ \\
Majority block & $17.57 \%$ \\
Joint exit & $18.92 \%$ \\
Board representation & $16.22 \%$ \\
\hline \hline Shareholders that are contracting with CEO/owner-manager \\
\hline Inside directors & $65.82 \%$ \\
Industrial companies & $12.65 \%$ \\
Venture capitalists & $21.52 \%$ \\
Institutional investors & $8.86 \%$ \\
\hline \hline
\end{tabular}




\section{Table 5: Definition of variables}

\begin{tabular}{|c|c|}
\hline Variable name & Description \\
\hline Market-to-book ratio & $\begin{array}{l}\text { Ratio of the first-day market capitalization and the post-issue book } \\
\text { value of equity. The post-issue book value of equity equals the sum of } \\
\text { the primary offering proceeds (i.e., number of newly issued shares } \\
\text { times the offer price) and the book value of equity from the last pre- } \\
\text { IPO financial statement, or when available from a later interim } \\
\text { statement as disclosed in the prospectus. Market-to-book ratio of } \\
\text { equity is censored at its } 5^{\text {th }} \text { and } 95^{\text {th }} \text { percentile }\end{array}$ \\
\hline Price-to-book ratio & $\begin{array}{l}\text { Ratio of the preliminary offer value to the pre-IPO book value of } \\
\text { equity from the last pre-IPO financial statement, or when available } \\
\text { from a later interim report included in the prospectus. The preliminary } \\
\text { offer value equals the number of pre-IPO shares times the minimum } \\
\text { tender price (in case of auctioned IPOs), the midpoint of the price } \\
\text { range (in case of bookbuilt IPOs) or the fixed-offer price (in case of } \\
\text { fixed-price offerings) }\end{array}$ \\
\hline Price-to-cash flow ratio & $\begin{array}{l}\text { Ratio of the preliminary offer value and the earnings before interest, } \\
\text { taxes, depreciation, amortization (EBITDA) and provision allowances } \\
\text { for the last } 12 \text { month period reported in the prospectus }\end{array}$ \\
\hline $\begin{array}{l}\text { Cash flow ownership owner- } \\
\text { manager }\end{array}$ & $\begin{array}{l}\text { Post-IPO stock cash flow ownership of the CEO/owner-manager. The } \\
\text { ownership is expressed as a percentage of post-IPO shares outstanding }\end{array}$ \\
\hline $\begin{array}{l}\text { (Cash flow ownership owner- } \\
\text { manager) }\end{array}$ & Cash flow ownership of the owner-manager squared \\
\hline Votes per cash flow right & $\begin{array}{l}\text { Ratio of post-IPO voting rights and cash flow rights in the hands of the } \\
\text { CEO/owner-manager }\end{array}$ \\
\hline Shareholder agreement dummy & $\begin{array}{l}\text { Equal to one if the CEO/owner-manager has entered into a shareholder } \\
\text { agreement with other pre-IPO shareholders, zero otherwise }\end{array}$ \\
\hline Power per cash flow right & $\begin{array}{l}\text { Ratio of } Z \text {-index of voting power of owner-manager and cash flow } \\
\text { ownership of owner-manager. The } Z \text {-index is a game-theoretic power } \\
\text { index that measures the probability that the outcome of the voting } \\
\text { process changes when the owner-manager changes his mind } \\
\text { unilaterally, assuming that all vectors of votes are equally likely (see } \\
\text { Figure 1) }\end{array}$ \\
\hline Sales & $\begin{array}{l}\text { Sales (in millions } € \text { ) during the last } 12 \text { month financial period reported } \\
\text { in the prospectus }\end{array}$ \\
\hline Age & $\begin{array}{l}\text { Difference between the IPO year and the founding year in the } \\
\text { prospectus }\end{array}$ \\
\hline Cash flow margin & $\begin{array}{l}\text { Ratio of earnings before interest, taxes, depreciation, amortization } \\
\text { (EBITDA) and provision allowances to sales for the last } 12 \text { months } \\
\text { reported in the prospectus. Cash flow margin is censored at its } 5^{\text {th }} \text { and } \\
95^{\text {th }} \text { percentile }\end{array}$ \\
\hline Plant, property and equipment & $\begin{array}{l}\text { Plant, property and equipment expressed as a percentage of total assets. } \\
\text { Plant, property and equipment is taken from the last pre-IPO balance } \\
\text { sheet, or when available from a later interim balance sheet as disclosed } \\
\text { in the prospectus }\end{array}$ \\
\hline Technology dummy & $\begin{array}{l}\text { Equal to one if a company belongs to the technology sector, zero } \\
\text { otherwise }\end{array}$ \\
\hline Manufacturing dummy & $\begin{array}{l}\text { Equal to one if a company belongs to the manufacturing sector, zero } \\
\text { otherwise }\end{array}$ \\
\hline Nouveau Marché dummy & $\begin{array}{l}\text { Equal to one if a company is listed on the Nouveau Marché, zero } \\
\text { otherwise }\end{array}$ \\
\hline
\end{tabular}




\section{Table 6: Incentive and entrenchment effects}

Models (1-5) are estimated through least-squares regressions. We use the natural logarithm of the market-to-book ratio of equity as the dependent variable in all regressions. All variables are defined in Table 5. Heteroskedastic-consistent $t$-statistics are within parentheses. significant at the $10 \%$ level; ${ }^{* *}$ significant at the $5 \%$ level; ${ }^{* * *}$ significant at the $1 \%$ level. The inflection point is the point at which the owner-manager becomes entrenched and his ownership becomes negatively related to firm value.

\begin{tabular}{|c|c|c|c|c|c|}
\hline & Model (1) & Model (2) & Model (3) & Model (4) & Model (5) \\
\hline Cash flow ownership & $0.842{ }^{* 051)^{* *}}$ & $\begin{array}{l}1.213 \\
(2682)^{* * *}\end{array}$ & 0.723 & $1.614)^{* * *}$ & 1.547 (3252)*** \\
\hline $\begin{array}{l}\text { owner-manager } \\
\text { (Cash flow ownership }\end{array}$ & $\begin{array}{l}(2.051) \\
-0.743\end{array}$ & $\begin{array}{l}(2.682) \\
-1.122\end{array}$ & $\begin{array}{l}(1 . / 15) \\
-0.556\end{array}$ & $\begin{array}{l}(3.405) \\
-1.537\end{array}$ & $\begin{array}{l}(3.252) \\
-1.398\end{array}$ \\
\hline owner-manager) $^{2}$ & $(-1.652)^{*}$ & $(-2.189)^{* *}$ & $(-1.642)^{*}$ & $(-2.890)^{* * *}$ & $(-2.562)^{* *}$ \\
\hline Votes per cash flow right & & $\begin{array}{l}-0.155 \\
(-2.149)^{* *}\end{array}$ & & & $\begin{array}{l}-0.048 \\
(-0.581)\end{array}$ \\
\hline $\begin{array}{l}\text { Shareholder agreement } \\
\text { dummy }\end{array}$ & & & $\begin{array}{l}0.128 \\
(1.998)^{* *}\end{array}$ & & $\begin{array}{l}0.136 \\
(2.068)^{* *}\end{array}$ \\
\hline Power per cash flow right & & & & $\begin{array}{l}-0.127 \\
(-3.450)^{* * *}\end{array}$ & $\begin{array}{l}-0.118 \\
(-2.734)^{* * *}\end{array}$ \\
\hline \multicolumn{6}{|l|}{ Control variables } \\
\hline $\log (1+$ sales $)$ & $\begin{array}{l}-0.096 \\
(-2.562)^{* *}\end{array}$ & $\begin{array}{l}-0.101 \\
(-2.734)^{* * *}\end{array}$ & $\begin{array}{l}-0.097 \\
(-2.672)^{* * *}\end{array}$ & $\begin{array}{l}-0.103 \\
(-2.800)^{* * *}\end{array}$ & $\begin{array}{l}-0.106 \\
(-2.981)^{* * *}\end{array}$ \\
\hline $\log (1+$ age $)$ & $\begin{array}{l}-0.106 \\
(-2.357)^{* *}\end{array}$ & $\begin{array}{l}-0.102 \\
(-2.239)^{* *}\end{array}$ & $\begin{array}{l}-0.102 \\
(-2.325)^{* *}\end{array}$ & $\begin{array}{l}-0.105 \\
(-2.383)^{* *}\end{array}$ & $\begin{array}{l}-0.099 \\
(-2.324)^{* *}\end{array}$ \\
\hline Cash flow margin & $\begin{array}{l}0.951 \\
(2.514)^{* *}\end{array}$ & $\begin{array}{l}0.916 \\
(2.502)^{* *}\end{array}$ & $\begin{array}{l}0.876 \\
(2.348)^{* *}\end{array}$ & $\begin{array}{l}0.927 \\
(2.554)^{* *}\end{array}$ & $\begin{array}{l}0.838 \\
(2.364)^{* *}\end{array}$ \\
\hline $\begin{array}{l}\text { Plant, property and } \\
\text { equipment }\end{array}$ & $\begin{array}{l}-0.774 \\
(-3.053)^{* * *}\end{array}$ & $\begin{array}{l}-0.823 \\
(-3.172)^{* * *}\end{array}$ & $\begin{array}{l}-0.761 \\
(-3.093)^{* * *}\end{array}$ & $\begin{array}{l}-0.804 \\
(-3.237)^{* * *}\end{array}$ & $\begin{array}{l}-0.803 \\
(-3.280)^{* * *}\end{array}$ \\
\hline Technology dummy & 0.015 & 0.004 & 0.021 & 0.007 & 0.011 \\
\hline & $(0.184)$ & $(0.058)$ & $(0.252)$ & $(0.091)$ & $(0.133)$ \\
\hline Manufacturing dummy & $\begin{array}{l}-0.189 \\
(-2.592)^{* *}\end{array}$ & $\begin{array}{l}-0.204 \\
(-2.807)^{* * *}\end{array}$ & $\begin{array}{l}-0.185 \\
(-2.549)^{* *}\end{array}$ & $\begin{array}{l}-0.196 \\
(-2.723)^{* * *}\end{array}$ & $\begin{array}{l}-0.195 \\
(-2.763)^{* * *}\end{array}$ \\
\hline Nouveau Marché dummy & $\begin{array}{l}-0.347 \\
(-4.205)^{* * *}\end{array}$ & $\begin{array}{l}-0.342 \\
(-4.400)^{* * *}\end{array}$ & $\begin{array}{l}-0.327 \\
(-3.874)^{* * *}\end{array}$ & $\begin{array}{l}-0.308 \\
(-3.699)^{* * *}\end{array}$ & $\begin{array}{l}-0.286 \\
(-3.373)^{* * *}\end{array}$ \\
\hline Intercept & $\begin{array}{l}2.125 \\
(9.654)^{* * *}\end{array}$ & $\begin{array}{l}2.254 \\
(9.888)^{* * *}\end{array}$ & $\begin{array}{l}2.089 \\
(9.406)^{* * *}\end{array}$ & $\begin{array}{l}2.210 \\
(10.119)^{* * *}\end{array}$ & $\begin{array}{l}2.206 \\
(9.802)^{* * *}\end{array}$ \\
\hline Year dummies & Yes & Yes & Yes & Yes & Yes \\
\hline $\mathrm{R}^{2}$ adjusted (\%) & 24.257 & 25.038 & 25.027 & 26.749 & 27.465 \\
\hline$F$-statistic & $7.362^{* * *}$ & $7.221^{* * *}$ & $7.217^{* * *}$ & $7.801^{* * *}$ & $7.269^{* * *}$ \\
\hline Inflection point (\%) & 56.7 & 54.1 & 65.0 & 52.5 & 55.3 \\
\hline Number of observations & 299 & 299 & 299 & 299 & 299 \\
\hline
\end{tabular}




\section{Table 7: Robustness checks}

We conduct several sensitivity analyses. In Columns (1) we re-estimate Model (5) of Table 6 without year dummies and without the votes per cash flow right variable. In Columns (2) and (3) we re-estimate Model (5) of Table 6 for 201 Second Marché IPO firms and for 98 Nouveau Marché IPO firms, respectively. We also use alternative dependent variables to capture IPO firm value. In Column (4) we use the price-to-book ratio. In Column (5) we use the price-to-cash flow ratio as the dependent variable. All variables are defined in Table 5 . Heteroskedastic-consistent $t$-statistics are within parentheses. ${ }^{*}$ significant at the $10 \%$ level; ${ }^{* *}$ significant at the $5 \%$ level; ${ }^{* * *}$ significant at the $1 \%$ level.

\begin{tabular}{|c|c|c|c|c|c|}
\hline & \multicolumn{5}{|c|}{ Dependent variable } \\
\hline & \multicolumn{3}{|c|}{ Market-to-book ratio of equity } & \multirow[b]{2}{*}{$\begin{array}{l}\text { Price-to- } \\
\text { book ratio }\end{array}$} & \multirow{2}{*}{$\begin{array}{l}\text { Price-to- } \\
\text { cash flow } \\
\text { ratio }\end{array}$} \\
\hline & $\begin{array}{l}\text { All IPO } \\
\text { firms }\end{array}$ & $\begin{array}{l}\text { Second } \\
\text { Marché }\end{array}$ & $\begin{array}{l}\text { Nouveau } \\
\text { Marché }\end{array}$ & & \\
\hline Cash flow ownership & 1.440 & $1.049 *$ & 2.144 & 1.815 & 2.749 \\
\hline owner-manager & $(3.157)^{* * *}$ & $(1.694)^{*}$ & $(2.345)^{* *}$ & $(3.446)^{* * *}$ & $(3.953)^{* * *}$ \\
\hline $\begin{array}{l}\text { (Cash flow ownership } \\
\text { owner-manager) }^{2}\end{array}$ & $\begin{array}{l}-1.237 \\
(-2.322)^{* *}\end{array}$ & $\begin{array}{l}-0.827 \\
(-1.171)\end{array}$ & $\begin{array}{l}-2.455 \\
(-2.092)^{* *}\end{array}$ & $\begin{array}{l}-1.705 \\
(-2.843)^{* * *}\end{array}$ & $\begin{array}{l}-2.692 \\
(-3.602)^{* * *}\end{array}$ \\
\hline Shareholder agreement & 0.146 & 0.196 & 0.089 & 0.135 & 0.127 \\
\hline dummy & $(2.144)^{* *}$ & $(2.292)^{* *}$ & $(0.752)$ & $(1.651)^{*}$ & $(1.663)^{*}$ \\
\hline Power per cash flow right & $\begin{array}{l}-0.114 \\
(-3.233)^{* * *}\end{array}$ & $\begin{array}{l}-0.126 \\
(-2.492)^{* *}\end{array}$ & $\begin{array}{l}-0.073 \\
(-1.272)\end{array}$ & $\begin{array}{l}-0.216 \\
(-5.239)^{* * *}\end{array}$ & $\begin{array}{l}-0.243 \\
(-3.928)^{* * *}\end{array}$ \\
\hline \multicolumn{6}{|l|}{ Control variables } \\
\hline $\log (1+$ sales $)$ & $\begin{array}{l}-0.111 \\
(-3.177)^{* * *}\end{array}$ & $\begin{array}{l}-0.152 \\
(-3.614)^{* * *}\end{array}$ & $\begin{array}{l}0.014 \\
(0.211)\end{array}$ & $\begin{array}{l}-0.167 \\
(-3.852)^{* * *}\end{array}$ & $\begin{array}{l}-0.085 \\
(-1.703)^{*}\end{array}$ \\
\hline $\log (1+$ age $)$ & $\begin{array}{l}-0.093 \\
(-2.164)^{* *}\end{array}$ & $\begin{array}{l}-0.095 \\
(-1.907)^{*}\end{array}$ & $\begin{array}{l}-0.085 \\
(-1.055)\end{array}$ & $\begin{array}{l}-0.150 \\
(-2.858)^{* * *}\end{array}$ & $\begin{array}{l}-0.025 \\
(-0.436)\end{array}$ \\
\hline Cash flow margin & $\begin{array}{l}0.624 \\
(1.684)^{*}\end{array}$ & $\begin{array}{l}0.476 \\
(0.853)\end{array}$ & $\begin{array}{l}0.673 \\
(1.225)\end{array}$ & $\begin{array}{l}0.119 \\
(0.247)\end{array}$ & $\begin{array}{l}1.110 \\
(1.829)^{*}\end{array}$ \\
\hline $\begin{array}{l}\text { Plant, property and } \\
\text { equipment }\end{array}$ & $\begin{array}{l}-0.835 \\
(-3.372)^{* * *}\end{array}$ & $\begin{array}{l}-0.987 \\
(-2.804)^{* * *}\end{array}$ & $\begin{array}{l}-0.277 \\
(-0.865)\end{array}$ & $\begin{array}{l}-0.445 \\
(-1.421)\end{array}$ & $\begin{array}{l}-1.246 \\
(-4.247)^{* * *}\end{array}$ \\
\hline Technology dummy & $\begin{array}{l}0.005 \\
(0.055)\end{array}$ & $\begin{array}{l}-0.080 \\
(-0.677)\end{array}$ & $\begin{array}{l}0.142 \\
(1.130)\end{array}$ & $\begin{array}{l}-0.001 \\
(-0.005)\end{array}$ & $\begin{array}{l}-0.185 \\
(-1.604)\end{array}$ \\
\hline Manufacturing dummy & $\begin{array}{l}-0.194 \\
(-2.706)^{* * *}\end{array}$ & $\begin{array}{l}-0.246 \\
(-3.030)^{* * *}\end{array}$ & $\begin{array}{l}-0.075 \\
(-0.459)\end{array}$ & $\begin{array}{l}-0.281 \\
(-3.284)^{* * *}\end{array}$ & $\begin{array}{l}-0.201 \\
(-2.508)^{* *}\end{array}$ \\
\hline Nouveau Marché dummy & $\begin{array}{l}-0.209 \\
(-2.443)^{* *}\end{array}$ & & & $\begin{array}{l}0.305 \\
(2.783)^{* * *}\end{array}$ & $\begin{array}{l}0.606 \\
(5.961)^{* * *}\end{array}$ \\
\hline Intercept & $\begin{array}{l}2.001 \\
(9.462)^{* * *}\end{array}$ & $\begin{array}{l}2.319 \\
(8.470)^{* * *}\end{array}$ & $\begin{array}{l}1.174 \\
(3.807)^{* * *}\end{array}$ & $\begin{array}{l}2.455 \\
(8.442)^{* * *}\end{array}$ & $\begin{array}{l}2.344 \\
(6.662)^{* * *}\end{array}$ \\
\hline Year dummies & No & No & No & Yes & Yes \\
\hline $\mathrm{R}^{2}$ adjusted (\%) & 24.311 & 30.750 & 5.655 & 40.756 & 33.232 \\
\hline$F$-statistic & $9.702^{* * *}$ & $9.881^{* * *}$ & 1.581 & $13.059^{* * *}$ & $9.725^{* * *}$ \\
\hline Inflection point $(\%)$ & 58.2 & 63.4 & 43.7 & 53.2 & 51.1 \\
\hline Number of observations & 299 & 201 & 98 & 299 & 299 \\
\hline
\end{tabular}




\section{Table 8: Private benefits of control}

This table shows averages for five proxies for private benefits of control. We split the sample firms both by full control $(Z$-index $=1)$ versus shared control $(Z$-index $<1)$ and by stock market segment (Second Marché versus Nouveau Marché). We measure the number of family directors related to the owner-manager (by blood or marriage) that serve on the board as a non-executive director and divide this by the total number of executive and non-executive directors. This proxies for nepotism. The two-tier board is a dummy variable that equals one if the owner-manager adopts the two-tier board structure, 0 otherwise. This proxies for power and prestige. Salary is the cash compensation of the entire board in the year before the IPO, divided by the total number of executive and non-executive directors. This proxies for selfdealing. Family name is a dummy variable that equals one if the firm carries the family name of the owner-manager. This proxies for status and prestige. Regional business is a dummy variable that equals one if the company is located outside Paris, Lyon, Marseille and Lille (the four largest French cities with more than one million inhabitants). Owner-managers of regional businesses are more likely to be important employers in that region, which gives them more status in their local community.

\begin{tabular}{lccc}
\hline \hline & $Z$-index=1 & $Z$-index $<1$ & $t$-statistic \\
\hline All IPO firms & & & \\
Family directors & $23.89 \%$ & $7.00 \%$ & $7.905^{* * *}$ \\
Two-tier board & $4.43 \%$ & $18.44 \%$ & $3.946^{* * *}$ \\
Salary ('000) & 86.83 & 99.17 & $2.490^{* * *}$ \\
Family name & $40.32 \%$ & $20.25 \%$ & $4.256^{* * *}$ \\
Regional business & $49.37 \%$ & $34.04 \%$ & $2.703^{* * *}$ \\
Number of observations & 158 & 141 & \\
Second Marché & & & \\
\hline Family directors & $27.04 \%$ & $7.83 \%$ & $7.198^{* * *}$ \\
Two-tier board & $5.08 \%$ & $22.06 \%$ & $3.459^{* * *}$ \\
Salary ('000) & 92.02 & 109.20 & $2.815^{* * *}$ \\
Family name & $25.42 \%$ & $6.02 \%$ & $3.672^{* * *}$ \\
Regional business & $51.69 \%$ & $37.35 \%$ & $2.020^{* *}$ \\
Number of observations & 118 & 83 & \\
Nouveau Marché & & & \\
\hline Family directors & $14.60 \%$ & $5.83 \%$ & $2.540^{* *}$ \\
Two-tier board & $2.50 \%$ & $15.52 \%$ & $2.119^{* *}$ \\
Salary ('000) & 71.11 & 84.61 & $1.676^{*}$ \\
Family name & $5.00 \%$ & $1.72 \%$ & 0.920 \\
Regional business & $42.50 \%$ & $29.30 \%$ & 1.347 \\
Number of observations & 40 & 58 & \\
\hline \hline
\end{tabular}




\section{Publications in the Report Series Research* in Management}

\section{ERIM Research Program: "Finance and Accounting"}

\section{5}

Royal Ahold: A Failure Of Corporate Governance

Abe De Jong, Douglas V. Dejong, Gerard Mertens en Peter Roosenboom

ERS-2005-002-F\&A

http://hdl.handle.net/1765/1863

Capital Structure Policies in Europe: Survey Evidence

Dirk Brounen, Abe de Jong and Kees Koedijk

ERS-2005-005-F\&A

A Comparison of Single Factor Markov-Functional and Multi Factor Market Models

Raoul Pietersz, Antoon A. J. Pelsser

ERS-2005-008-F\&A

Efficient Rank Reduction of Correlation Matrices

Igor Grubišić and Raoul Pietersz

ERS-2005-009-F\&A

Generic Market Models

Raoul Pietersz and Marcel van Regenmortel

ERS-2005-010-F\&A

The price of power: valuing the controlling position of owner-managers in french ipo firms Peter Roosenboom and Willem Schramade

ERS-2005-011-F\&A

The Success of Stock Selection Strategies in Emerging Markets: Is it Risk or Behavioral Bias? Jaap van der Hart, Gerben de Zwart and Dick van Dijk ERS-2005-012-F\&A

Sustainable Rangeland Management Using a Multi-Fuzzy Model: How to Deal with Heterogeneous Experts' Knowledge Hossein Azadi, Mansour Shahvali, Jan van den Berg and Nezamodin Faghih ERS-2005-016-F\&A

\footnotetext{
* A complete overview of the ERIM Report Series Research in Management: https://ep.eur.nl/handle/1765/1

ERIM Research Programs:

LIS Business Processes, Logistics and Information Systems

ORG Organizing for Performance

MKT Marketing

F\&A Finance and Accounting

STR Strategy and Entrepreneurship
} 